\title{
Albanian Model of Free Zones: Implementation and Implications
}

\author{
Çeljeta Sherifi ${ }^{1} \&$ Güngör Turan ${ }^{1}$ \\ ${ }^{1}$ Economics Department, Epoka University, Tirana, Albania \\ Correspondence: Celjeta Sherifi, Departament of Economics, Epoka University, Rruga Tirane-Rinas, Km.13. \\ Tirana, Albania. Tel: 355-672-087-029. E-mail: celjetasherifi@gmail.com
}

Received: February 26, 2018

Accepted: March 17, 2018

Online Published: March 25, 2018

doi:10.5539/ijef.v10n5p57

URL: https://doi.org/10.5539/ijef.v10n5p57

\begin{abstract}
Free economic zones are structures playing a special role in the direct and continuous interconnections between a country and the other part of the world. In other words, free economic zones are easily opened doors to international markets. This paper brings a theoretical view on the concept of the Free Economic Zones, their characteristics, as well as their importance in countries economy. It also aims to discus about creation, implementation and management of technical economic development areas in Albania. The benefits they could provide to Albanian economy based on a variety of positive and potential factor that Albania is currently offering. Through learning the best experience of some successfully implemented free economic zones in the world, this study helps to better identify the factors that play an important role in increasing the economic and industrial potential of Albania.
\end{abstract}

Keywords: free economic zone, FDI, employment, economic growth, incentives, Albanian model

\section{Introduction}

All Countries of the world are trying to bring some dynamic and long term solutions for their economic growth, foreign trade balance and increasing employment opportunities. For this reason, inside an environment of strong trade competition market, they are thinking how to increase their market share in the global trade. This can be done by the development of the free economic zones, as part of the government interventions. When we think about the free economic zones first thing that come across the mind is a specific area inside any country with special economic privileges, where a large number of enterprises are fund and where the goods are produced, exported or imported. Free economic zones are structures playing a special role in the direct and continuous interconnections between a country and the other part of the world. In other words, free economic zones are easily opened doors to international markets.

The first modern free economic zone was established in Shannon, Ireland in 1959, but after that China has been one of the countries that has implemented lots of special economic zones during 1980s. There are lots of success stories such as Shenzhen Free Zone in China which have turned form a totally small lost city into an industrialized cosmopolitan city. At the same time, ports in Dubai or Singapore which are utilized as regions to do extensive variety of exchange thought a very good logistic and infrastructure and serve as free ports are part of other success stories. (Chen, 1995) made a detailed study on how the export processing zones or special economic zones play an important role not only in the diversification and increasing of exports but also he emphasizes the impact that those zones have in political, cultural and social areas. According to a study carried out by The Economist newspaper actually there are more than 4,000 SEZs operating in the world by creating new job opportunities for around 68 million people.

In general, free economic zones can be defined as need for "import" in developed countries, and "export" for developing countries. Many developing countries applied a strategy from importing substitutions to exporting promotions after 1970s. Adoption of export oriented strategies, has leaded in the expansion of free zones. Free economic zone topic is one of the important topics discussed not only in Albania but also in the region. During all the bilateral meetings between the official visits, TEDAs in Albania are being promoted in order to find the appropriate and successful investor. Government of Albania decided to implement the industrial park and economic zone concept in 2006 but their attempt failed. Regardless some changes done recently on the Law of Free Zones by turning them into technological and economic development zones, still the experimentation phase has not started yet. Ministry of Economic Development, Tourism, Trade and Entrepreneurship in Albania as well 
as Albanian Investment Development Agency (AIDA) are the responsible entities for the creation, coordination and administration of those zones and till now they have prepared all the legal framework as well as they have carried the feasibility studies for all interested parties. In Albania, actually there is no active free economic zone. During 2014, Government has created three Technical and Economic Development Areas (TEDAs) located in Koplik, Spitalla and Vlora and is looking for a private investor to develop and operate those Areas. Increasing of the foreign direct investments, generation of employment and positive impact in the economic growth together with acceleration of technology transfer will be some of benefits that our country will have from the implementations of TEDA's.

The second part of the paper includes the literature view related with free economic zones, their characteristics, purpose and variety. The last part is related to Albania's economy model, evolution of FEZ's and factors why Albania do not have any Free Economic Zone implementation till now.

\section{Free Economic Zones in Literature}

The Free Economic Zones are being utilized by countries as a system to build up their economies, particularly by expanding their fare to outside nations. Diverse sort of definitions are used in the literature for naming trade zones. World Bank defines free zones as "fenced-in areas that specialize in manufacturing for exports that offer firms free trade conditions and a liberal regulatory environment". According to another study "a free zone can be defined as a stimulation of a domestic economy by upgrading technology and human capital" (Zeng, 2010). Similarly, a study of OECD defines the free zone as "a government policy to promote exports of goods and/or services by offering a more competitive business environment through provision of special incentives including particular tariff exemptions to inputs in a geographically defined area" (Engman et al., 2007). Some of the definitions used are Free Zone, Free Port, Customs Free Zone, Customs Free Airport, Tax Free Zone, Free Production Zone, Foreign Trade Zone, Special Economic Zone, Export Processing Zone, Free Economic Zone, Free Trade Zone, Industrial Free Zone and so on. The reason of this assortment in terminology is related with kind of process developed in those zones by every nation. The principle reason to build up a free economic zone is to create economic activities, to increase production and employment, to minimize bureaucracy related with investments and trade, to facilitate import and to gain new dimension to international trade.

The first modern economic zone was established in Shannon Free Zone in Ireland, 1959. This was a zone that Irish Government used to increase and promote the employment in rural cities. Application was so successful, that other countries didn't lose time to establish and expand those Economic Zones for its benefits in their economy. East Asia and Latin America, initiated EPZ programs. In the 1980s, the pace of zone development increased and expanded to new regions, including South Asia (Bangladesh, Pakistan), South America, and sub-Saharan Africa (Mauritius). The first privately developed and operated zones came on line in the Caribbean and Central America in the 1980s. Since then, zone development has exploded with the emergence of new programs in the countries of Eastern and Central Europe, the Commonwealth of Independent States, and Middle East and North Africa.

Zone policies have now been set up in more than 130 countries worldwide (most of which are in the developing world). In 2008, it was estimated that the nearly 3,000 zones in operation generate on the order of 70 million jobs and contribute $\$ 500$ billion annually in direct trade-related value added. Special economic zones have transformed worldwide shipping practices, and have facilitated the global expansion of developed-world capital (Akinci \& Crittle, 2008). Now the number of SEZ seems to be over 5,000.

The greatest example of a success story is China, whose choice in 1980 to make a zone in Shenzhen changed the city to a boomtown, with growing its domestic economy and lifting millions people out of poverty. Since 1982 China's SEZs have all been creating at an unfathomable pace. Shenzhen itself has been particularly successful. Today, Shenzhen is a fare arranged economy with an export value of $\$ 48$ billion, 30 billion FDI and more than 3 million directly employed (Akinci \& Crittle, 2008).

India also has used the Chinese SEZs policy to implement within the country borders (Briefing, 2011). In India, the first zone was established in Kandla in 1965. The fundamental target of setting up EPZs in India was promoting of export and increase of trade exchange. The approaches were non- flexible and the bundle of incentives was not alluring as there was no single window office inside of the zone in the primary phases. But later on, after the establishment of FEZ's, the share of EPZ exports to total exports has shown a very gradually rising trend (Aggarwal, 2004).

In case of Bangladesh, it has a population from around 150 million, with a large potential of textile and jute production. During 1950-1960 nearly 80\% of world's jute was derived from Bangladesh, but later on, due to development of synthetic substitutes it created an export gap. This gap wall filled by foreign investors mainly 
from Middle East which took advantage of country's low labor cost, and they started production of garments. During 1980's Bangladesh Government applied EFZ program, which was really a catalyst to country's economy. From 50 factories now Bangladesh has more than 4,500 factories, employing more than 2 million people contributing 75 percent of the country's total export earnings. By providing all the needed infrastructure for FEZ's Bangladesh now is one of the successful stories of FEZ's applications (Farole \& Akinci, 2011)。

After taking into consideration some of success stories in the implementation of FEZs it is possible to say that some of the main purposes of FEZs are:

- The development not only in infrastructure facilities but also country's economy by the promotion of additional economic activities.

- To minimize the bureaucracy in all of commodity inflow and outflow processes, as well as customs procedures.

- To bring modern technology for the development of industry,

- Promotion of export of services and commodities,

- To increase the foreign direct and domestic investments,

- Increase the employment.

There are lots of advantages that free economic zones offers to the countries they are being implemented. Some of the main advantages are free duties during the import and export in and out of those zones. Government plays an important role to add other benefits such as tax benefits and financial incentives. Inside the free economic zones there is lots of tax, social- political and structural advantages. The most important element for the free economic zones is the removal of the restrictions that prevent the growth of entrepreneurs.

\subsection{Types of Free Zones}

Free zone concept varies according to the country's economic structure. Free zones can be encountered in various applications according to their objectives, functions, legal structures etc. These different applications arise due to the economic and geographical structure of the country, related national regulations or jurisdiction of customs. Maybe this kind of division cannot have definite boundaries, however it may be possible to classify on the basis of two criteria. A first criterion is related to the type of operations in the free zone. The free zone can promote only commercial activities, can have an industrial type nature, can be a production site or it can be a combined activity field. The second criterion is the interior area of operations. Some economic zones can be oriented toward domestic market; some of them are export- oriented. Generally the developed countries prefer domestic market oriented free economic zones (Rhee et al., 1990).

These zones may be administered by a private company, public-private partnership (PPP), by local, regional or national government. Different countries have developed different type of free zones according to the government's focus to increase exports, to gain FDI, to develop a specific sector within the country, to bring high technology, increase employment etc. Some of the model preferred form countries around the world are given as below.

Table 1. Models of FZs in different countries

\begin{tabular}{|c|c|c|}
\hline Model & Description & Countries \\
\hline \multirow[t]{3}{*}{ Special Economic Zones } & - Attract FDI & China \\
\hline & - Increase Employment & Malaysia \\
\hline & - Fiscal Incentives by specific Authority & \\
\hline \multirow[t]{3}{*}{ Export Processing Zone } & - Aim to increase the exports & Philippines;Mauritius \\
\hline & - Do not have tax incentives & Bulgaria; Slovenia \\
\hline & - Good geographic location in order to attract a specific area of investment. & Thailand \\
\hline \multirow[t]{2}{*}{ Enterprise Zones } & - Incentives that help in boosting production and manufacturing for a specific area. & USA; England \\
\hline & & Italy; France \\
\hline \multirow[t]{2}{*}{ Free Trade Zone } & - Location near to seaports/airports/border & Chile \\
\hline & - provide lots of facilities for trade ( storage, warehouse etc) & Poland \\
\hline \multirow[t]{3}{*}{ Single Factory } & - Improvement of a single factory in order to increase the export for a specific & Mauritius \\
\hline & industry in which government thinks can help in improving hosting country's & Mexico \\
\hline & economy. & \\
\hline \multirow[t]{2}{*}{ Free Ports } & - Aim to increase human capital & India \\
\hline & - Focused on tourism and retail sales & Philippines \\
\hline
\end{tabular}


- Export processing zones, according to Johansson and Nilsson EPZs are "geographically bounded areas in which free trade, including duty free import of intermediate goods, is permitted provided that all goods produced within the zone are exported" (Nilsson, 1997). World Bank publications define export processing zones as area which is implemented exclusively for export markets (Akinci \& Crittle, 2008). The main purpose of those zones is to accelerate the export growth as well as to diversify the exports.

- $\quad$ Free Trade Zone generally is defined as a zone situated within or near an airport, seaport less than 50 hectares yet isolated from the encompassing national domain where facilitated commerce, transshipment, re-exporting, storage, production are the main economic activities (Akinci \& Crittle, 2008).

- Single Factory EPZ (or free enterprises) are a variation on EPZs or free zones, where incentives and privileges are offered to individual enterprises, which can locate anywhere in the country.

- TEDA, Technical and Economic Development Areas are manufactured - base special economic zones that have preferential policies and privileges with advance technology (Guangwen, 2013). China is one of the countries that has implemented the TEDA in most of its region. The main difference between TEDA's and other free economic zones is that they are based on manufacturing in different fiels such as industry, agriculture,tourism etc. by creation of technologic and scentific research institutions with a direct impact on industralization process of hosting countries (Zheng, 1987). While free economic zones can be both industry and service bases, TEDAs prefer production side, by mean of innovation in technology.

There are different criteria to measure the success of a free zone. Of course, the most important one is the FDI attraction, but factors like employment, export, economic growth provided, skill and technology transfer are some of the factors by which a free zone is defined to be successful or not (Asa \& Jahed, 2015). According to Farole and Akinci (2011) the factors for successful economic zones are grouped into: physical criteria's (it is related with the infrastructure of economic zones), chosen model (PPP, Government, private etc), policy framework and institutional framework.

Government support by economic reforms is very important for developing successful economic zones. It includes tools aimed to improve economic efficiency by change in the competitiveness legislature or regulatory tools in markets which are little or no compete. Economic reforms aim to protect and to provide a general level of prosperity in areas such as social regulation, health, safety environment etc. Administrative regulation, as well as arrangements for the bureaucratic and administrative processes effects stands on secondary importance for the economy but still they are very important to take into consideration. It is very crucial for the investors to find a stable and macro-environment. First of all, the central government should support a specific policy for economic zones. The creation of a friendly investment environment is done by special policy that clearly specifies the zone's criteria, includes the incentives provided by the government, authorization of a special institution which will manage the area, the presence of a responsive management for the demands of entrepreneurs. All the rights and obligations of the investors also should be clearly specified.

Thinking about which model to chose, governments should pick up the most appreciate developing model which relies on countries aggressive point of interest in which they can build a long term competitive advantages. EZs projects ought to be a piece of the national or territorial plan based on country's strategic economic developments, employment capacity, infrastructure benefits, land availability, specific need for the improvement of a target industry, as well as row material input quantity and quality, neighborhoods economic situation and their needs, inventory network land and work supply etc. Choosing the appropriate activities in the free zones and not allowing negative competition between the activities carried out on the same subject is very important.

\section{Free Zones in Albania}

Albanian is a small country with a population of 2.8 million and is one of the countries that have made a difficult transition from a closed economy to a modern and open economy. The real GDP growth rate has been stable from 2004-2007 averaged around 5.5\%, in 2008 macroeconomic growth was at maximum 7.5\%. In 2009 despite the crisis Albania had one of the highest rates of growth in Europe at a level of 3.3\%. Real GDP growth of Albania has slowed down during last years. Crisis that hit the neighborhood countries especially Greece and Italy resulted to a decrease in remittances (as a large number of Albanian works in those countries) and also decrease in trade exchange. On the other hand, Albania is a rich country in water reserves and a hydropower potential energy, hydrocarbons, minerals such as chromium, copper, iron, coal which can easily attract foreign investors.Albania is called "Europe's Last Secret" (Godwin, 2011), or "The best-kept secret in the Mediterranean" (Shearing, 2015) due to a great potential of tourism and its geographical diversity.

For the first time free zones in Albania were discussed in 1991, using the press to start an open debate to a 
subject that has been a taboo for 50 years during the communism. But in order to switch on the "green light" it would take 5 years more. National Office of Free Zones was established on the basis of the law Nr. 8072 and date 15.2.1996 "On Free Zones". Lost time was filled with political declarations and promises, so that poor people remembered that Albania will wake up a nice day as a total "free zone". Political figures of that time, who had taken over the heavy burden of running ex-communist state and one of Europe's poorest economies, thought to identify "original" ways for a country which urgently needs investments to improve its basic infrastructure and raise the living standard. Shortly after the publication of the law, a small team of researchers were charged to take care of implementing a new administration office which would be responsible of the legislation, strategy, investors etc. According to similar practices of the other countries, Albanian Government of that time chooses Durres as a possible first pilot area in which a successful "free zone" could be implemented.

According to the law, investors investing in this area would be exempted from income tax during the first 7 years. Another Law entered into force in 2000 (law number 8639, date 6.7.2000) which changed the duration of the exemption from seven to ten. Shortly after the publication of the law some American, Italian, Turkish, Greek, etc. companies have shown their interest to come and invest in Albania. But this interest was quickly dissuaded, only after 6 months. In December of the same year, the parliament that voted the law, repealed section 3 of Article 18, by cancelling the exclusion of free income tax for 10 years without taking care of the developments that it himself promoted.

In 2008, the government of Albania voted a special law for the creation of "Economic Zones" in order to gain and encourage investments. 9 economic zones, 8 of which were designed as industrial park and 1 as a free zone were part of a modernization process and transformation to a market economy. Albanian Ministry of Economy, launched 8 industrial parks:

- Koplik: The Industrial Park in Koplik, Shkoder, approved on January 4, 2008. With an area of 61 hectares, for industrial production activities, trade, agri-processing etc.

- Shengjin: Industrial Park with an area of 3,2 hectares.

- Elbasan: Industrial Park with an area of 254,7 hectares in the region of the former Metallurgic Plant.

- Durres: Industrial Park in Spitalle, Durres, with an area of 850 hectares, state and privately owned area.

- Vlora: Industrial Park in Vlora.

- Shkoder: The Industrial Park includes the former industrial center with an area of 137 hectares.

- Lezha: Industrial Park of Lezha, proposed by the municipality of Lezha and approved on 27 January 2009.

- Tirana: Industrial Park of Tirana approved on 22 July 2009 in Laknas.

- And one free Zone "Vlora Free Zone" approved by the government on 11 June 2009.

But due to some problems with land ownership, infrastructure issues, ineffective promotional campaign and lack of enforcement of contracts and inventive packages those announced zones were not successful. Creation of Free Zones or alternative types of them in Albania are unfortunately a failure story of our economic authorities. Policy makers have been unable to define and develop the necessary vision, model, legal framework and actualization of Free Zones. Yet, today we do not have any operating Free Zone or alternative of it, and this is inacetable for a developing country.

According to the new law No. 54/2015 entered into force, the areas defined as "industrial parks" or " free zones" were replaced by "Technological and Economic Development Area" TEDA which is defined, again according to the law as a "separate territory, a designated area of land or buildings and other immovable properties, developed in accordance with a general plan and provided with the relevant infrastructure for production, industrial development, trade and provision of services, which is estimated part of the customs territory of the Republic of Albania, separate from this territory in terms of fiscal and customs regime and which is governed in accordance with the provisions of this law, other legal and sub-legal acts for its enforcement."

Table 2. Advantages of TEDA in Albania

\begin{tabular}{ll}
\hline Model & \multicolumn{1}{c}{ Advantages } \\
\hline - Exemption from the profit tax rate for $50 \%$ for a period of 5 years. \\
- Within 3 years of commencement of economic activity, the annual capital expenses are $20 \%$ deductible. \\
- Supply of Albanian goods, are considered as a supply for export at zero scale. \\
- Wages and social costs are $150 \%$ deductible for the first year, and new expenses for wages and social costs \\
\hline
\end{tabular}




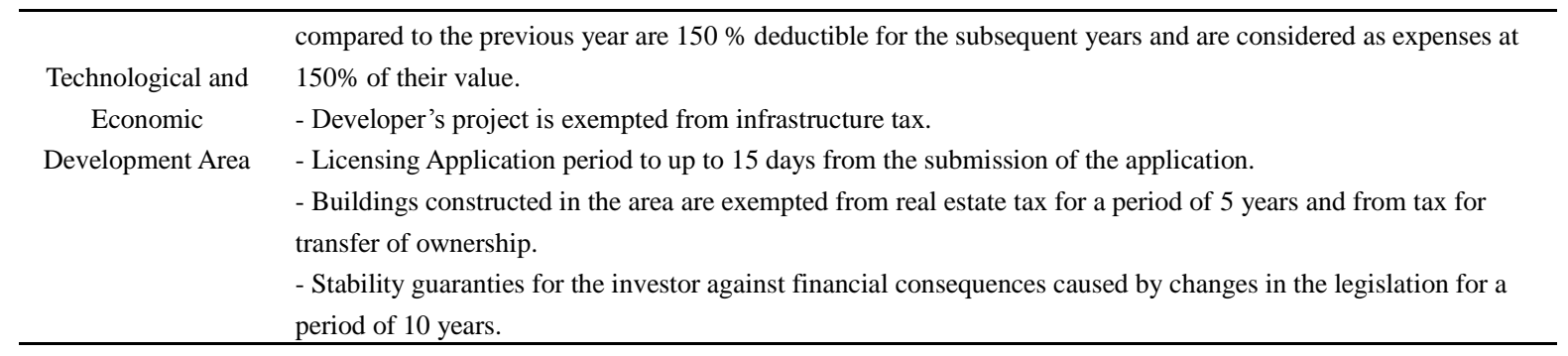

Source: Republic of Albania, Directorate for Technical and Economic Development Areas.

But trying to develop Free Zones without a clear economic development model of a country economy is destined to be a failure. Whatever these economic priorities are, it should be clearly defined, modeled and developed and only than you can have the proper vision for the development of Free Zones. What are the products/goods that we can compete, what is their geographical spread through the country and what are the priorities in decreasing costs? These are few questions that need to be answered among many regarding our economic model and only than we can use Free Zones in our benefit. The legal framework is also another challenge to be faced when we are talking about Free Zones. They need to be simple, transparent and without bureaucratic obstacles. The incentive packages should be flexible and based on the economic development needs of specific products and areas, not only fiscal incentives work but you can generate alternative incentives. The economic framework will help development; and then Free Zones will help our economy. A regulating authority is needed not only to promote one or two zones but to coordinate and help the policymakers to spread with the Free Zones according to their growth needs.

\section{Free Zones in the Region}

\subsection{Free Zones in the Macedonia}

Macedonia is one of the most successful states in the region for making the economic zones functional. Macedonian Government, other than awarding the land for use with very attractive prices, has also offered exemptions from taxes in the initial 3-10 years of business operation (depending on the type of business production). They also offer exemption from taxes on profit up to $50 \%$ on 5 initial years for the domestic employees hired by the firm. The government itself has engaged in offering assistance and training in developing the businesses with the aim to attract investors to Macedonia, contrary to other countries in the Balkans. "Macedonia: Tax haven in Balkan" would be some of the main national and international newspapers titles, in order to promote and at the same time to consider the importance of free zones implementation in Macedonia. The government was promoting the construction of free zones in Macedonia as important tools to gain a significant number of investors, to increase employment and export, and of course improving important economic indicators. In 2002 Macedonian government created a "Free Zone Authority" responsible for the implantation and promotion of free zones. Years after, in order to attract foreign investors Government implemented a special strategy to make the FDI primarily important, and to speed up the economy.

There are three economic fully operational zones in Macedonia known as Technological-Industrial Development Zones (TIDs) established to introduce modern technologies in order to improve the economic environment.

\section{Skopje 1}

The total area: 140.18 hectares.

Location: $10 \mathrm{~km}$ east of Skopje,

OwnerShip: $100 \%$ state owned

\section{Skopje 2}

The total area: 96.75 hectares.

Location: $10 \mathrm{~km}$ east of Skopje,

OwnerShip: $100 \%$ state owned

3. Stip

The total area: 206.43 hectares.

Location: Stip

OwnerShip: $100 \%$ state owned 
The zone in Tetovo (94.74 hectares) is operating as a public private partnership (PPP), and also there are 11 other zones that are under construction and development. These are: Free Zone Skopje 3, Prilep, Struga, Strumica, Kicevo, Gevgelija, Berovo, Delcevo, Radovis, Rankovce, and Vinica.

Quality regulation, significant improvements in the elimination of barriers, competitiveness level and market development have been some aspects affecting the investment climate. (Tosheva, 2016). According to the World Doing Business 2017 Report Macedonia was ranked the 10th out of 189 country's economies. The most important publication related with the ease of doing business ranked Macedonia as the second best performer country in the according the indicator "Starting a Business" as it has only one procedure for the companies that want to invest in Macedonia. (World Bank, 2016).

Table 3. Incentives in Technological-Industrial Development Zones in Macedonia

\begin{tabular}{lcc}
\hline & Inside Zone & Outside Zone \\
\hline Corporate Tax & $0 \%$ ( up to 10 years) & $10 \%$ \\
Personal Income Tax & $0 \%$ ( up to 10 years) & $10 \%$ \\
Value Added Tax & $0 \%$ & $18 \%$ \\
Excise Tax & $0 \%$ & $5-62 \%$ \\
Equipment, machines and spare parts & $0 \%$ & $5 \%-20 \%$ \\
Land & 99 years long term lease & \\
Taxes to local municipality & $0 \%$ & \\
\hline
\end{tabular}

Source: Republic of Macedonia, Directorate for Technological Industrial Development Zones.

Beside the incentives, Government of Macedonia provide to the investors free connection of natural gas, water, sewage network and according to the amount of investment it can participate up to 50,000 Euro in the construction infrastructure. Macedonian Government in collaboration with the Agency for Foreign Investment have been working a lot for a good promotion of economic zones to turn FDI into an important tool for the country's integration in international markets.

\subsection{Free Zones in Kosovo}

Free zones in Kosovo are defined as "Economic Zones" according the Law on Economic Zones 04/L-159, where the definition of "Economic Zone" means a geographical area within the state territory, which has a special economic status, created for the purpose of promotion and development of businesses. In the municipalities they are known as business parks, industrial parks or as business incubators. Free economic zones are currently not allocated on the basis of specific activities. Within such a zone there are different operating businesses, which, by the nature of their activity, should not be near to each other. The first initiative on establishing an economic zone was made in 2005, with the establishing of Business Park in Drenas. Economic Zones in Kosovo, operating legally, established based on the legislation, are 3, as follows:

\section{Business Park, Drenas}

The total area: 24 hectares.

Location: Drenas, $22 \mathrm{~km}$ along the highway Prishtina - Peja

OwnerShip: $100 \%$ state owned

\section{Business Park, Mitrovica}

The total area: 3.5 hectares.

Location: Mitrovica, $1 \mathrm{~km}$ from the highway connecting Kosovo with Serbia

OwnerShip: $100 \%$ state owned

\section{Business Park, Skenderaj}

The total area: 19.63 hectares.

Location: Cadastral zone of Lower Kline

OwnerShip: $100 \%$ state owned

Whereas, the other initiatives of Economic Zones in Kosova are as follows:

- Industrial Zone in Suhareka 
- $\quad$ Dutch Industrial Park (Zinkunie) - Prizren

- Business Park - Vushtrri

- Technology Park - Shtime

- $\quad$ Economic Zone - Gjilan / Kamenica

- $\quad$ Economic Zone - Ferizaj

\section{Comparing Region Countries}

Among all the countries in the region that have established FEZs Serbia has the highest number of zones. These zones are also the most developed zones in the region, since they were established earlier than the other countries in the region. The other country after Serbia with the most developed free zones is Macedonia. The zones in this country have proven to offer more than one thousand jobs, a number which is expected to increase in the following years. However, Albania and Kosova's free economic zones are not as developed. Creation of the Zone Authority responsible for the management of the zones is a "must" for a successful development. The authority in charge for the regulatory function, company's orientation, institutional arrangements etc. will provide to the investor all the information they need. In Macedonia the Free Zones Authority was established in 2002, while in Albania do not exist a specified institution for the management of the TEDAs, where all interested tenants can get the information starting from the opening stage. Sometimes, the implication of too much institution responsible for TEDAs developments is not ease, especially for Balkan culture of work. That's why it is so important that the authority should have a clear picture of what is responsible for. If the development of the free economic zones in all these countries of the region were to be successful, the whole region will benefit from it. It will increase the trade between region countries themselves and with the rest of the south east and central Europe.

According to the experience in the world's free zones the main factors that leads to a successful zone are the policy and incentive package offered from the government to the investors, the location of the zone and the way it is managed. As the location of the free zones in Albania is favorable, relatively near the sea ports and airports as well as near to the neighborhood countries border, the main failure seems to be the government's policy and incentive frameworks.

Are the legal incentives and regulatory frameworks of the Albanian Government competitive if compared to other countries of region such as Macedonia or Kosovo? In order to have a better idea let's have a look at the table below. Please, note that some of values are missing for Kosovo, since this country is still in the process of finalizing legal framework and most of details still are not decided.

Table 4. Government incentives in Macedonia Kosovo and Albania

\begin{tabular}{lccc}
\hline & Macedonia & Kosovo & Albania \\
\hline Tax Holiday & 10 years & 5 years & 5 years \\
- Profit tax & $0 \%$ & $0 \%$ & $50 \%$ \\
- Personal Income Tax & $0 \%$ & NA & $10 \%-23 \%$ \\
- Excise Tax & $0 \%$ & NA & $0 \%$ only for exports \\
- Value Added Tax & $0 \%$ & NA & $0 \%$ only for exports \\
Land Usage & 99 years & NA & 99 years \\
Local Government Incentives & YES & YES & YES \\
Exemption from payment of customs & YES & YES & YES \\
Training cost & Government (10 years) & NA & Doubly deductible (10 years) \\
\hline
\end{tabular}

Source: Respective Free Zone Authorities and Ministries.

On the other hand, the economic stability and government reform not only inside the zones but also the investment climate in general are very important factor for the attraction of the foreign investors. If we have a closer look on how the Balkan countries are ranked in 2017 Doing Business report:

10. FYR Macedonia

47. Serbia

51. Montenegro

58. Albania 


\section{Kosovo}

\section{Bosnia and Herzegovina}

Macedonia has been very aggressive toward region competitiveness and attraction for foreign investors. The positive impact of the free zones has been observed in indirect employment as well as in the increase of exports. Montenegro has shown improvements in dealing with construction permit and paying taxes. It has implemented electronic systems to fill labor taxes also. Kosovo also made paying taxes easier by introducing an online system for filing and paying VAT and social security contributions, and it made paying taxes less costly. Serbia, on the other hand by undergoing some business regulatory, has mange to be one of the preferable countries for foreign investors. Albania was ranked as the county in which doing business is not easy. The main problem of Albania's economy is juridical system (courts), changes in legislation of tax procedure and informal competition. World Bank tries to make a clear picture for all of the foreign investors which are interested to start a new business in SEE countries. This is why big companies choose to invest primary to Macedonia or Serbia, and leaving the other countries in a second plan.

\section{Conclusions}

All Countries of the world are thinking how to increase their market share in the global trade inside an environment of strong competition. This can be done by the development of the free economic zones, as part of the government interventions. Developed countries are using the free economic zones as tools mainly to increase the exports, while developing countries are using them to in order to attract foreign capital, to boost production, to introduce new technology and increase foreign trade exchange. However, the expected benefits of the free trade zone is not limited to solve the problem of unemployment by creating new job opportunities, increasing the direct investments or enabling a faster integration into the world economy.

Some of the main advantages of free zones are the positive impacts in imports and exports, as the producing company does not need to choose the goods from another country, to follow the procedures in the customs which can last long. Another important contribution of free zones is in the income generation and employment, which has a positive effect on the country's economic growth.

Among all the countries in the region that have established FEZs Serbia has the highest number of zones. These zones are also the most developed zones in the region, since they were established earlier than the other countries. The other country after Serbia with the most developed free zones is Macedonia. The zones in this country have proven to offer more than one thousand jobs, a number which is expected to increase in the following years. However, Albania and Kosova's free economic zones are not as developed. Kosovo has recently tried to develop the free economic zones. Meanwhile in Albania, due to some problems with land ownership, infrastructure issues, ineffective promotional campaign and lack of enforcement of contracts and inventive packages, the announced free zones were not successful. Creation of Free Zones or alternative types of them in Albania are unfortunately a failure story. The main reason is because there isn`t a clear economic development model of our county. Trying to develop Free Zones without a clear economic development model, economy is destined to be a failure. It should be clearly defined, modeled and developed and only than you can have the proper vision for the development of Free Zones. The legal framework is also another challenge to be faced when we are talking about Free Zones. They need to be simple, transparent and without bureaucratic obstacles.

\section{References}

Aggarwal, A. (2004). Export Processing Zones in India: Analysis of the Economic Performance. Working Paper No. 148. New Delhi: Indian Council of Research in International Economic Relations.

Agjencia Shqiptare e Zhvillimit të Investimeve, AIDA. (2013). Renewable Energy in Albania Brochure 2013.

Agjencia Shqiptare e Zhvillimit të Investimeve, AIDA. (2015). Albania Calls 2015.

Akinci, G., \& Crittle, J. (2008). Special economic zone: performance, lessons learned, and implication for zone development. Foreign Investment Advisory Service (FIAS) occasional paper. Washington, DC: World Bank.

Albanian General Directory of Custom. Retrieved from www.dogana.gov.al

Asa, P. R., \& Jahed, M. (2012). Factors in Free trade - Industrial. Singaporean Journal of Business Economics and Management Studies, 1(5).

Bangladesh Export Processing Zones Authority. Retrieved from www.epzbangladesh.org.bd

Briefing, C. (2011). Understanding Development Zones in China. China Briefing Magazine. Retrieved from http://www.china-briefing.com/news/2011/10/05/understanding-development-zones-in-china.html 
Chen, X. (1995). The Evolution of the Free Economic Zones and the Recent Development of Cross. International Journal of Urban and Regional Research, 19. https://doi.org/10.1111/j.1468-2427.1995.tb00530.x

Directorate for Technological Industrial Development Zones, Macedonia. Retrieved from http://www.dtirz.com/zones/free-zone-skopje-3/

Engman, M., Onodera, O., \& Pinali, E. (2007). Export Processing Zones: Past and Future Role in Trade and Development. OECD Trade Committee (May 2007). http://dx.doi.org/10.1787/035168776831

Farole, Th., \& Akinci, G. (2011). Special Economic Zones, Progress, Emerging Challenges, and Future Directions (pp. 37-47). The International Bank for Reconstruction and Development/ The World Bank. https://doi.org/10.1596/978-0-8213-8763-4

Fund, I. M. (2013). Country Report (p. 11). International Monetary Fund.

Godwin, N. (2011). Albania: Europe's last secret. Travel Weekly Newspaper.

Guangwen, M. (2013). The Theory and Practice of Free Economic Zones: A Case Study of Tianjin. People's Republic of China, Tianjin / PRC

ILO. (2014). Trade Union manual on Export Processing Zones. Geneve: International Labour Organization.

IMF. (2016). Albania Country Report.

Johansson, H., \& Nilsson, L. (1997). Export Processing Zones as Catalysts. World Development Organization, 25. https://doi.org/10.1016/S0305-750X(97)00103-4

Këshilli i Investimeve në Shqipëri. Retrieved from https://www.investment.com.al

Ministry of Economic Development, Turism, Trade and Entrepreneurship, Albania. Retrieved from www.ekonomia.gov.al

Ministry of Foreign Affairs, Kosovo. Retrieved from http://www.mfa-ks.net/?page=2,198

Rhee, Y. W., Katterbach, K., \& White, J. (1990). Free Trade Zones in Export Strategies. Washington DC: The World Bank.

Shearing, C. (2015). Albania: the best-kept secret in the Mediterranean? London: The Telegraph Newspaper.

Technical and Economic Development Areas in Albania. Retrieved from www.teda.gov.al

The Economist. (2015). SEZ, Not so Special. Space and the city, 4 April, p. 9.

Tosheva, E. (2016). The effects of the global economic crisis on Macedonian economy: Some macroeconomic indicators and future policy recommendations. University St. Clement of Ohrid, Bitola. https://doi.org/10.7336/academicus.2016.13.14

World Bank. (2016). Doing Bussines 2016.

Zeng, D. Z. (2010). Building Engines for Growth and Competitiveness in China: Experience with Special Economic Zones and Industrial Clusters (Vol. 1). Washington, DC: World Bank. https://doi.org/10.1596/978-0-8213-8432-9

Zheng, H. R. (1987). The Legal Structure of Economic and Technological Development Zones in the People's Republic of China. Berkeley Journal of International Law, 5(1). https://doi.org/10.15779/Z38M93W

\section{Copyrights}

Copyright for this article is retained by the author(s), with first publication rights granted to the journal.

This is an open-access article distributed under the terms and conditions of the Creative Commons Attribution license (http://creativecommons.org/licenses/by/4.0/). 